\title{
MEDIA PEMBELAJARAN MATEMATIKA BERBASIS ANDROID PADA MATERI PROGRAM LINEAR
}

\author{
Putri Nandita Apsari ${ }^{1)}$, Swaditya Rizki ${ }^{2)}$ \\ ${ }^{1,2)}$ Universitas Muhammadiyah Metro \\ E-mail: putri.nanditaa@yahoo.com ${ }^{1)}$, swadityarizki@ummetro.ac.id ${ }^{2)}$
}

\begin{abstract}
The objective of this research and development was to produce a product of learning media based on android that were valid and practical to use for the student. This research type was Research and Development $(R \& D)$. The model used in this research was ADDIE model consisting of 5 stages. The instruments of data collection used the questionnaires product validation by experts and practicality by students. Based on the validations process were obtained the result that the developed learning media fulfill very feasible category, with the average percentage of $84.5 \%$, which means that developed learning media was very valid. While the results of small group trials were obtained the result that the response of the students who numbered 10 students with an average of $88.1 \%$ stated strongly agree which means learning media developed was very practical. Based on predetermined criteria, the android-based mathematics learning media on linear program material developed fulfill the valid and practical criteria.
\end{abstract}

Keywords: android, learning media, linear programming, $R \& D$

\section{PENDAHULUAN}

Pendidikan adalah pembelajaran pengetahuan, keterampilan, dan kebiasaan sekelompok orang yang ditransfer dari satu generasi ke generasi berikutnya melalui pengajaran, pelatihan, atau penelitian. Pendidikan memegang peran penting dalam peningkatan mutu sumber daya manusia sehingga dalam pendidikan selalu ada hal menarik yang harus terus dipelajari dan dikembangkan. Hal menarik yang dapat dikembangkan terutama oleh pendidik salah satunya adalah media pembelajaran.

Menurut Peraturan Pemerintah Nomor 19 Tahun 2005 Tentang Standar Nasional Pendidikan bahwa "Guru sebagai pendidik harus memiliki kualifikasi akademik dan kompetensi sebagai agen pembelajaran. Kompetensi sebagai agen pembelajaran pada jenjang pendidikan dasar dan menengah meliputi kompetensi Pedagogik, kepribadian, profesional, dan sosial." Salah satu unsur kompetensi Pedagogik adalah guru mampu mengembangkan dan memanfaatkan media dan sumber belajar. Oleh karena itu guru dituntut dapat mengembangkan media pembelajaran dalam proses pembelajaran.

Menurut Sukmadinata (2011) bahwa penelitian dan pengembangan adalah suatu proses atau langkahlangkah untuk mengembangkan suatu produk baru atau menyempurnakan produk baru yang telah ada, yang dapat dipertanggungjawabkan. Produk tersebut tidak selalu berbentuk benda atau perangkat keras (hardware), seperti buku, modul, alat bantu pembelajaran di kelas atau laboratorium, tetapi bisa juga perangkat lunak (software), seperti program komputer. Selain itu, menurut Rahmawati dan Rizki (2017) yang menyatakan bahwa penelitian dan pengembangan dalam bidang matematika perlu dilakukan sebagai inovasi untuk memudahkan siswa dalam memahami matematika. Salah satu inovasi yang bisa dikembangkan yaitu pengembangan bahan ajar, metode maupun media pembelajaran. Inovasi yang akan dikembangkan dalam penelitian pengembangan ini yaitu 
media pembelajaran berbasis andorid. Media pembelajaran itu sendiri adalah salah satu hal penting untuk selalu dikembangkan agar dapat memberikan layanan pendidikan kepada siswa agar dapat belajar secara mandiri.

Menurut Susilana dan Riyana (2009) menyatakan bahwa media merupakan bagian dari komunikasi. Baik buruknya sebuah komunikasi ditunjang oleh penggunaan saluran dalam komunikasi tersebut. Saluran/chanel yang dimaksud adalah media. Karena pada dasarnya pembelajaran merupakan proses komunikasi, maka media yang dimaksud adalah media pembelajaran. Salah satunya penelitian yang pernah dilakukan mengenai media berupa video pembelajaran oleh Purwanto dan Rizki (2015) yang menyatakan bahwa media video pembelajaran sangat baik digunakan dalam proses pembelajaran matematika.

Namun, berdasarkan observasi yang telah dilakukan di SMA Negeri 2 Metro kelas XI didapatkan bahwa pada proses pembelajaran matematika, media pembelajaran yang sering digunakan dalam penyampaian materi adalah berbentuk power point. Siswa diberi kebebasan untuk menggunakan media apapun dalam belajar matematika serta penggunaan teknologi sudah tidak asing lagi bagi sekolah tersebut dilihat dari keseharian siswa membawa smartphone dan laptop. Sekolah sudah menyediakan jaringan internet pada masing-masing kelas namun hanya beberapa guru yang memanfaatkan teknologi sebagai media yang dapat menunjang pembelajaran matematika.

Oleh karena itu, diperlukan sebuah media pembelajaran berbasis teknologi yang dapat memudahkan siswa dalam proses pembelajaran baik di dalam maupun di luar kelas. Media pembelajaran berbasis teknologi yang dapat dimanfaatkan salah satunya adalah smartphone android. Karena hasil survei yang dilakukan di SMA Negeri 2 Metro kelas XI IPA 1 sebanyak $97 \%$ pengguna smartphone android. Berdasarkan hal tersebut, sangat cocok apabila smartphone android digunakan sebagai media dalam pembelajaran matematika baik di dalam maupun di luar kelas. Huda (2013) menyatakan bahwa android merupakan sebuah sistem operasi berbasis linux yang didesain khusus untuk perangkat bergerak seperti smartphone atau tablet. Sistem operasi android bersifat open source sehingga banyak sekali programmer mengembangkan aplikasi maupun memodifikasi sistem operasi ini. Android merupakan suatu sistem operasi yang berjalan pada smartphone atau tablet PC yang bersifat open source sehingga banyak sekali programmer yang ingin membuat aplikasi sendiri salah satunya menjadi media yang dapat dimanfaatkan dalam proses pembelajaran yaitu media pembelajaran berbasis android.

Dari penjelasan di atas dapat disimpulkan bahwa dengan adanya media pembelajaran dapat mempengaruhi proses pembelajaran siswa. Oleh karena itu, tujuan dalam penelitian ini adalah untuk menghasilkan media pembelajaran matematika berbasis android pada materi program linear yang valid dan praktis untuk proses pembelajaran siswa kelas XI SMA Negeri 2 Metro.

\section{METODE PENELITIAN}

Model pengembangan yang digunakan dalam penelitian pengembangan ini adalah menggunakan model ADDIE (Analysis, Design, Development, Implementation, and Evaluation). Menurut Sutarti dan Irawan (2017) langkah-langkah dalam 
pengembangan produk ini menggunakan model pengembangan ADDIE (Analysis, Design, Development, Implementation, and Evaluation). Tahapan analisis mempunyai tujuan untuk mendapatkan informasi kebutuhan-kebutuhan yang digunakan untuk mengembangkan media pembelajaran sehingga diharapkan media yang dikembangkan dapat menunjang kegiatan belajar siswa. Pada tahap ini, diantaranya mengenai analisis kurikulum, analisis karakteristik siswa, dan analisis lingkungan sekolah.

Tahap desain yang dilakukan berupa merancang dan menyusun materi yang disajikan dalam media berbasis android dengan materi program linear menjadi sebuah aplikasi android yang disesuaikan dengan kompetensi dasar yang dicapai agar dapat dijadikan sebagai media pembelajaran.

Tahap pengembangan dimulai dengan memproduksi media pembelajaran, yaitu berupa aplikasi pembelajaran berbasis android. Sehingga tahap ini menghasilkan prototipe. Prototipe yang dihasilkan divalidasi oleh para ahli yaitu ahli materi dan ahli media untuk diberikan komentar dan saran agar dapat dilakukan proses perbaikan. Jika prototipe tersebut sudah divalidasi oleh ahli materi dan media maka prototipe tersebut dinyatakan layak atau tidak untuk diuji cobakan. Apabila dinyatakan layak oleh para ahli maka dilakukan revisi menjadi media yang siap diperbanyak dan dapat diuji cobakan oleh siswa.

Data yang dikumpulkan dalam penelitian pengembangan ini adalah data kualitatif dan data kuantitatif. Data kualitatif diperoleh dari hasil komentar/saran dari angket yang dinilai oleh para ahli yaitu ahli materi dan ahli media untuk validasi produk dan hasilnya digunakan untuk perbaikan. Data kuantitatif diperoleh dari hasil penskoran dari angket yang berupa deskripsi persentase kevalidan oleh para ahli dan kepraktisan produk oleh siswa. Instrumen pengumpulan data yang digunakan dalam penelitian ini adalah angket validasi produk oleh ahli dan angket kepraktisan produk oleh siswa.

Kisi-kisi angket validasi produk oleh para ahli dan kisi-kisi angket respon siswa yang diadaptasi dari Yahya (2015) adalah sebagai berikut:

Tabel 1. Kisi-Kisi Angket Validasi Produk Oleh Ahli Materi

\begin{tabular}{|c|c|c|}
\hline No & Aspek & Indikator \\
\hline 1 & $\begin{array}{l}\text { Kualitas Isi } \\
\text { dan Tujuan }\end{array}$ & $\begin{array}{l}\text { Kesesuaian dengan KD } \\
\text { Kejelasan tujuan pembelajaran } \\
\text { Kejelasan alur pembelajaran } \\
\text { Kesesuaian materi } \\
\text { Kejelasan materi yang disajikan } \\
\text { Kedalaman materi yang disajikan } \\
\text { Kemudahan memahami materi } \\
\text { Kualitas latihan soal } \\
\text { Ketepatan penggunaan bahasa }\end{array}$ \\
\hline 2 & $\begin{array}{l}\text { Kualitas } \\
\text { Pembelajaran }\end{array}$ & $\begin{array}{l}\text { Kejelasan petunjuk dalam penggunaan media } \\
\text { Ketepatan umpan balik latihan soal } \\
\text { Kemudahan dalam belajar } \\
\text { Sarana interaksi antara guru dengan siswa } \\
\text { Pembelajaran secara mandiri } \\
\text { Keinginan untuk mempelajari materi yang lain dengan media sejenis }\end{array}$ \\
\hline
\end{tabular}


ISSN 2089-8703 (Print) Vol. 7, No. 1 (2018)

ISSN 2442-5419 (Online)

Tabel 2. Kisi-Kisi Angket Validasi Produk Oleh Ahli Media

\begin{tabular}{|l|l|l|}
\hline \multicolumn{1}{|c|}{ No } & \multicolumn{1}{|c|}{ Aspek } & \multicolumn{1}{c|}{ Indikator } \\
\hline 1 & Keterpaduan & $\begin{array}{l}\text { Perpaduan warna } \\
\text { Kemudahan navigasi } \\
\text { Kejelasan petunjuk }\end{array}$ \\
\hline 2 & Keseimbangan & $\begin{array}{l}\text { Penempatan tombol } \\
\text { Tata letak tulisan }\end{array}$ \\
\hline 3 & Bentuk Huruf & $\begin{array}{l}\text { Kesesuaian jenis huruf } \\
\text { Kesesuaian ukuran huruf } \\
\text { Variasi ukuran dan jenis huruf } \\
\text { Keterbacaan teks/kalimat }\end{array}$ \\
\hline 4 & Warna & $\begin{array}{l}\text { Kesesuaian warna background } \\
\text { Kesesuaian warna tulisan } \\
\text { Kesesuaian warna tombol } \\
\text { Kemenarikan gambar dan animasi }\end{array}$ \\
\hline 5 & Bahasa & $\begin{array}{l}\text { Ketepatan bahasa } \\
\text { Ketepatan kalimat }\end{array}$ \\
\hline
\end{tabular}

Tabel 3. Kisi-Kisi Angket Respon Oleh Siswa

\begin{tabular}{|l|l|l|}
\hline No & Aspek & Indikator \\
\hline 1 & $\begin{array}{l}\text { Kualitas Isi } \\
\text { dan Tujuan }\end{array}$ & $\begin{array}{l}\text { Kejelasan petunjuk penggunaan } \\
\text { Kejelasan pembahasan materi } \\
\text { Kejelasan alur pembelajaran }\end{array}$ \\
\hline 2 & $\begin{array}{l}\text { Kualitas } \\
\text { Teknik }\end{array}$ & $\begin{array}{l}\text { Kejelasan tampilan, warna, navigasi } \\
\text { Keterbacaan teks } \\
\text { Latihan soal dan umpan balik } \\
\text { Kemudahan penggunaan aplikasi }\end{array}$ \\
\hline 3 & $\begin{array}{l}\text { Kualitas } \\
\text { Pembelajaran }\end{array}$ & $\begin{array}{l}\text { Kemudahan dalam belajar } \\
\text { Pemberian bantuan dalam belajar } \\
\text { Pembelajaran secara mandiri } \\
\text { Keinginan untuk mempelajari materi yang } \\
\text { lain dengan media sejenis }\end{array}$ \\
\hline
\end{tabular}

Pada tahap implementasi, prototipe yang sudah dihasilkan dalam tahap pengembangan diimplementasikan kepada pengguna pada situasi nyata di lapangan. Selama implementasi, rancangan media yang telah dikembangkan diterapkan pada kondisi yang sebenarnya. Uji coba dilakukan oleh siswa yaitu terbatas pada uji kelompok kecil sehingga menghasilkan media pembelajaran yang sudah direvisi berdasarkan validasi oleh ahli dan kepraktisan oleh siswa.
Teknik analisis penelitian pengembangan ini adalah analisis validasi produk dan analisis kepraktisan siswa. Menurut Riduwan dan Akdon (2013:18) persentase pada angket validasi tersebut dicari dengan menggunakan rumus sebagai berikut:

Persentase $=\frac{\text { jumlah skor yang diberikan validator }}{\text { jumlah skormaksimum }} \times 100 \%$

Kriteria validitas produk yang dihasilkan dinyatakan dalam Tabel 4. 
ISSN 2089-8703 (Print) Vol. 7, No. 1 (2018)

ISSN 2442-5419 (Online)

Tabel 4. Kriteria Kevalidan Suatu Produk

\begin{tabular}{|c|c|c|}
\hline $\begin{array}{c}\text { Bobot } \\
\text { Nilai }\end{array}$ & Kategori & Penilaian (\%) \\
\hline 5 & Sangat Layak & $\begin{array}{l}80<N \\
\leq 100\end{array}$ \\
\hline 4 & Layak & $60<N \leq 80$ \\
\hline 3 & Kurang Layak & $40<N \leq 60$ \\
\hline 2 & Tidak Layak & $20<N \leq 40$ \\
\hline 1 & Sangat Tidak Layak & $0<N \leq 20$ \\
\hline
\end{tabular}

Apabila hasil validasi yang diperoleh lebih dari $60 \%$ maka produk memenuhi kriteria layak sehingga dapat dikatakan valid dan dapat diuji cobakan dan apabila hasil respon siswa yang diperoleh lebih dari $60 \%$ maka produk dapat dikatakan praktis. Kriteria kepraktisan produk yang dihasilkan dinyatakan dalam Tabel 5:

Tabel 5. Kriteria Kepraktisan Suatu Produk

\begin{tabular}{|c|l|c|}
\hline $\begin{array}{c}\text { Bobot } \\
\text { Nilai }\end{array}$ & \multicolumn{1}{|c|}{ Kategori } & Penilaian (\%) \\
\hline 5 & Sangat Praktis & $80<N \leq 100$ \\
\hline 4 & Praktis & $60<N \leq 80$ \\
\hline 3 & Kurang Praktis & $40<N \leq 60$ \\
\hline 2 & Tidak Praktis & $20<N \leq 40$ \\
\hline 1 & Sangat Tidak Praktis & $0<N \leq 20$ \\
\hline
\end{tabular}

Setiap tahapan dalam pengembangan media selalu dilakukan evaluasi dengan mengumpulkan data yang digunakan untuk memperbaiki produk pengembangan yang dihasilkan. Evaluasi ini dilakukan untuk mengukur dan menilai produk pembelajaran yang dihasilkan dari angket validas olehi para ahli dan angket kepraktisan oleh siswa untuk mengetahui tingkat kelayakan produk.

\section{HASIL PENELITIAN DAN PEMBAHASAN}

Model media secara umum, terdapat Intro yang merupakan tampilan pembuka media sebelum masuk pada menu utama. Halaman ini menampilkan logo Universitas Muhammadiyah Metro dan materi yang disajikan. Pengguna dapat langsung masuk ke menu utama. Sedangkan menu utama terdiri dari petunjuk penggunaan, kompetensi dasar, materi dengan sub materi program linear, contoh soal dan evaluasi, dan Info dengan sub sejarah program linear dan profil.

Menu utama berisi menu petunjuk, kompetensi dasar, materi, dan info. Petunjuk berisi tentang tata cara menggunakan media dan dilengkapi dengan gambar-gambar menu yang tersedia pada media pembelajaran. KD berisi kompetensi dasar dan indikator materi program linear. Materi berisi sub menu yaitu Program Linear dan Evaluasi. Pada menu program linear terdapat menu Model Matematika, Nilai Optimum Fungsi Objektif, dan Penyelesaian Program Linear yang masing-masing terdapat 5 contoh soal beserta pembahasan setiap soalnya sehingga siswa dapat mengetahui penyelesaian soal dengan tepat. Menu 
ISSN 2089-8703 (Print) Vol. 7, No. 1 (2018)

ISSN 2442-5419 (Online)

evaluasi untuk mengerjakan latihan soal dari materi keseluruhan dengan login nama dan kelas. Evaluasi akan menampilkan skor yang akan diperoleh oleh siswa setelah menyelesaikan semua menu info berisi tentang sejarah program linear dan profil pengembang. Berikut ini sebagian tampilan media pembelajaran berbasis android yang dihasilkan:

soal yang ada di dalamnya. Selanjutnya

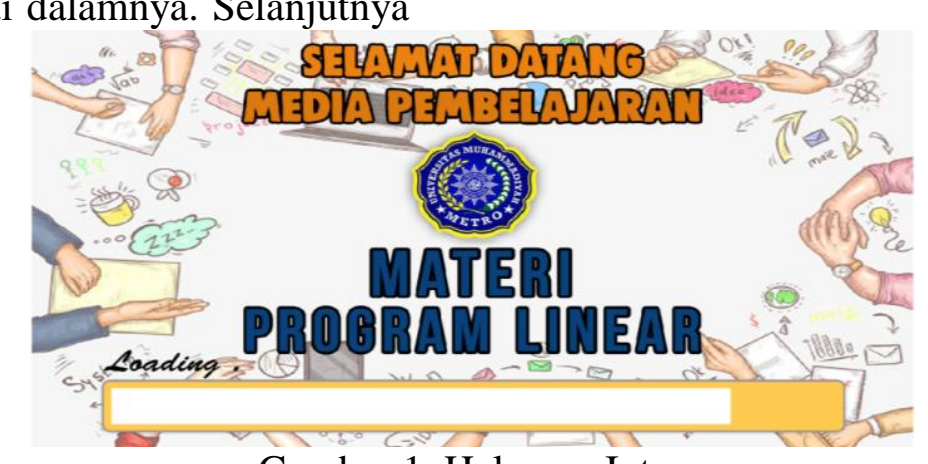

Gambar 1. Halaman Intro

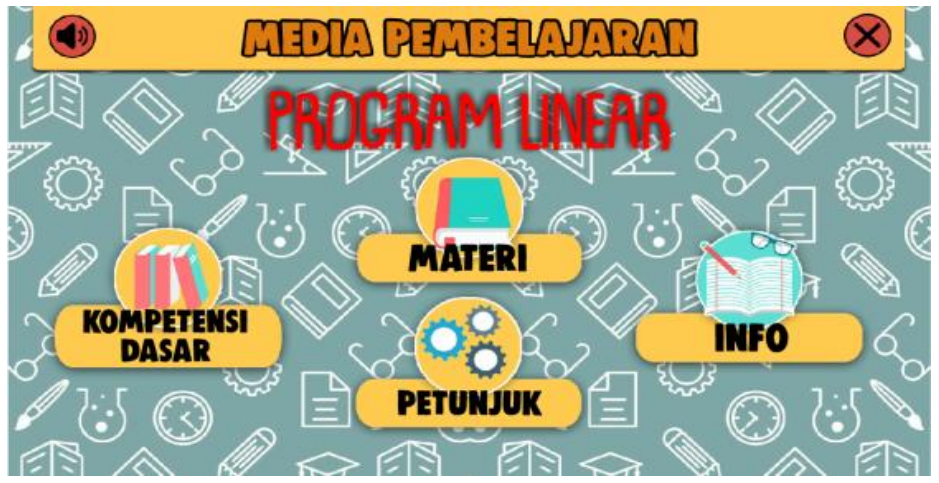

Gambar 2. Halaman Menu Utama.

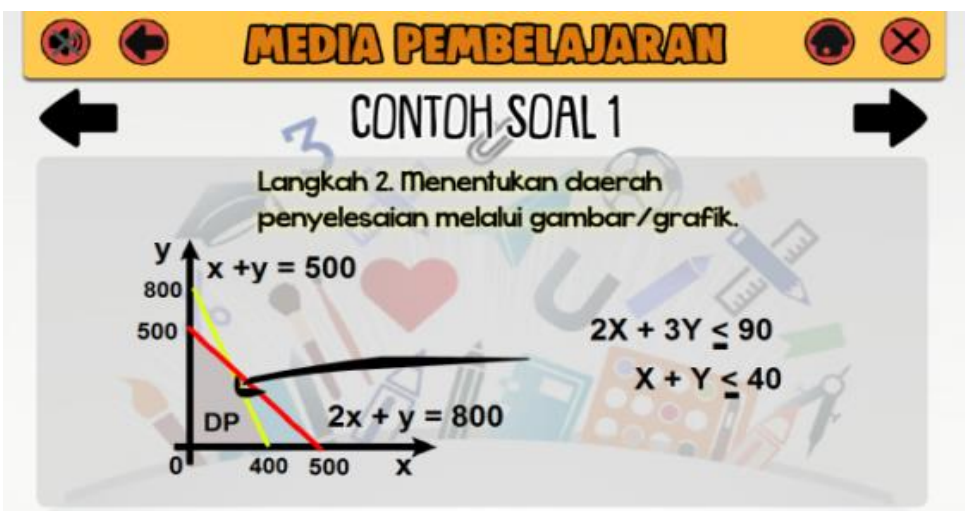

Gambar 3. Halaman Contoh soal. 
ISSN 2089-8703 (Print) Vol. 7, No. 1 (2018)

ISSN 2442-5419 (Online)

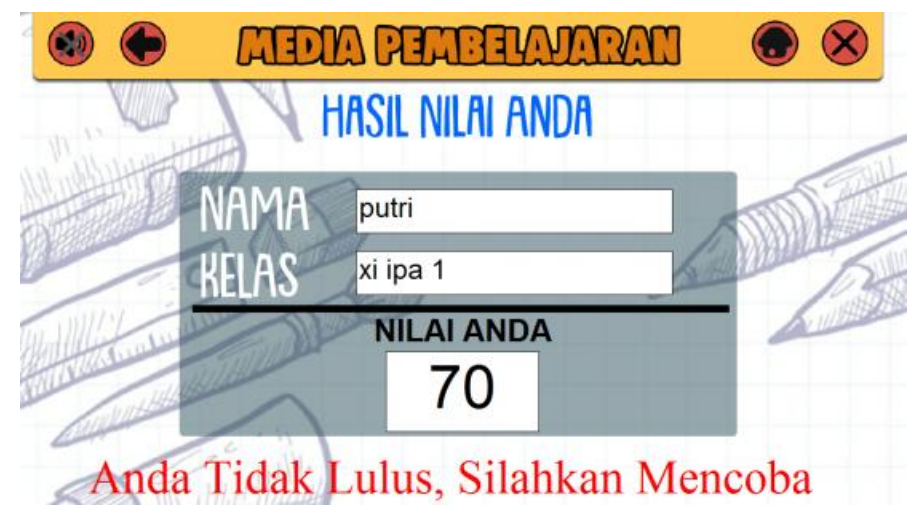

Gambar 4. Halaman Hasil Tes Evaluasi.

Berdasarkan hasil validasi yang dilakukan oleh 6 validator yaitu 3 ahli materi dan 3 ahli media. Hasil dari validasi terhadap para ahli diperoleh data adalah sebagai berikut:

Tabel 6. Data Hasil Angket Validasi Materi

\begin{tabular}{|c|c|c|c|}
\hline Validator & Nilai & Persentase & Kriteria \\
\hline Validator 1 & 59 & $78,67 \%$ & Layak \\
\hline Validator 2 & 68 & $90,67 \%$ & Sangat layak \\
\hline Validator 3 & 60 & $80 \%$ & Layak \\
\hline Jumlah & 187 & $83 \%$ & Sangat Layak \\
\hline
\end{tabular}

Tabel 7. Data Hasil Angket Validasi Media

\begin{tabular}{|c|c|c|c|}
\hline Validator & Nilai & Persentase & Kriteria \\
\hline Validator 1 & 59 & $78,67 \%$ & Layak \\
\hline Validator 2 & 70 & $93,3 \%$ & Sangat layak \\
\hline Validator 3 & 65 & $86,67 \%$ & Sangat Layak \\
\hline Jumlah & 194 & $86 \%$ & Sangat Layak \\
\hline
\end{tabular}

Tabel 8. Rata-Rata Persentase Tingkat Kelayakan Media Pembelajaran

\begin{tabular}{|c|c|c|}
\hline Validator & Persentase & Kategori \\
\hline Ahli Materi & $83 \%$ & Sangat Layak \\
\hline Ahli Media & $86 \%$ & Sangat Layak \\
\hline Rata-rata & $84,5 \%$ & Sangat Layak \\
\hline
\end{tabular}

Hasil persentase (\%) rata-rata yang diberikan oleh validator adalah $84,5 \%$ yang masuk dalam kategori sangat layak maka media pembelajaran matematika berbasis android sangat valid dan dapat diuji cobakan. Selanjutnya hasil uji coba pada kelompok kecil yang terdiri dari 10 siswa berupa angket respon siswa disajikan pada Tabel 9. 
ISSN 2089-8703 (Print) Vol. 7, No. 1 (2018)

ISSN 2442-5419 (Online)

Tabel 9. Data Respon Siswa Pada Uji Coba Kelompok Kecil

\begin{tabular}{|c|c|c|c|}
\hline Siswa & Jumlah & Persentase & Keterangan \\
\hline 1 & 67 & $89,3 \%$ & Sangat Praktis \\
\hline 2 & 70 & $93,3 \%$ & Sangat Praktis \\
\hline 3 & 73 & $97,3 \%$ & Sangat Praktis \\
\hline 4 & 67 & $89,3 \%$ & Sangat Praktis \\
\hline 5 & 72 & $96 \%$ & Sangat Praktis \\
\hline 6 & 60 & $80 \%$ & Praktis \\
\hline 7 & 65 & $86,67 \%$ & Sangat Praktis \\
\hline 8 & 61 & $81,3 \%$ & Sangat Praktis \\
\hline 9 & 62 & $82,67 \%$ & Sangat Praktis \\
\hline 10 & 64 & $85,3 \%$ & Sangat Praktis \\
\hline Jumlah & $\mathbf{6 6 1}$ & $\mathbf{8 8 , 1 \%}$ & Sangat Praktis \\
\hline
\end{tabular}

Hasil persentase (\%) rata-rata yang diberikan oleh siswa adalah $88,1 \%$ yang masuk dalam kategori sangat praktis, maka media pembelajaran matematika berbasis android sangat praktis. Berdasarkan hasil dari penelitian pengembangan yang diperoleh dapat disimpulkan bahwa media pembelajaran yang telah divalidasi oleh para ahli, dan diuji cobakan yaitu uji coba kelompok kecil dengan penilaian angket telah dilakukan revisi. Revisi tersebut sesuai komentar atau saran yang diberikan oleh validator dan siswa yang telah dinyatakan layak karena telah teruji kevalidannya oleh validator, praktis karena telah di uji coba pada kelompok kecil hingga memenuhi kriteria sangat praktis sehingga media pembelajaran matematika berbasis android mudah diakses dan dapat mendukung proses pembelajaran baik di dalam maupun di luar kelas.

Dari hasil ujicoba terbatas ke siswa bahwa media pembelajaran berbasis android dapat menarik minat siswa dalam proses pembelajaran, karena pembelajarannya menjadi menyenangkan. Selain itu, pembelajaran di era teknologi saat ini sudah menjadi keharusan bagi pendidik untuk memanfaatkan teknologi khususnya pembelajaran berbasis android dikarenakan hampir seluruh siswa saat ini menggunakan handphone dengan sistem operasi android. Hal ini sejalan dengan penelitian yang dilakukan oleh Purbasari, dkk (2012) dan Yahya (2015) yang menyatakan bahwa android dapat digunakan sebagai media pembelajaran matematika untuk menunjang proses pembelajaran.

Media pembelajaran berbasis android yang dikembangkan dilakukan evaluasi dan revisi pada tahap pengembangan yaitu validasi ahli dan uji coba kelompok kecil sehingga produk yang dihasilkan menjadi produk yang sangat valid dan praktis.

Media pembelajaran berbasis android ini memiliki beberapa kelebihan yaitu media ini memiliki tampilan desain yang menarik, baik dari segi warna, tulisan, gambar dan animasi. Media ini mudah dioperasikan, dipahami dan mudah dimengerti oleh siswa, tombol-tombol yang ada dalam media ini dapat berfungsi dengan baik sesuai petunjuk penggunaan media. Materi dan soal latihan sesuai dengan KD dan disertai dengan gambar dan animasi sehingga siswa tidak merasa bosan dalam menggunakannya.

Kelebihan lainnya yaitu media ini dapat digunakan secara mandiri baik di 
sekolah maupun di luar sekolah karena media ini mudah didapatkan melalui aplikasi share data. Media pembelajaran ini juga dilengkapi dengan pembahasan dan di akhir evaluasi terdapat hasil skor penilaian untuk mengetahui tingkat pencapaian siswa dengan menggunakan media pembelajaran ini.

Namun, disamping kelebihan tersebut ada beberapa kendala yang mungkin muncul pada saat penggunaan media pembelajaran berbasis android ini, salah satunya pada saat pembelajaran siswa memanfaatkan android untuk keperluan yang lain seperti bermain game, sosial media, dan lain sebagainya. Untuk mengatasi kemungkinan tersebut, peran guru sebaiknya mengawasi dan mengontrol siswa pada saat menggunakan media pembelajaran berbasis android dalam proses pembelajaran. Selain itu, untuk siswa yang memiliki kemampuan rendah akan sulit belajar secara mandiri menggunakan media pembelajaran berbasis android sehingga pada saat pembelajaran siswa harus selalu didampingi oleh guru.

\section{KESIMPULAN DAN SARAN}

Dari hasil penilaian yang dilakukan oleh ahli dan ujicoba ke siswa, maka dapat disimpulkan bahwa media pembelajaran matematika berbasis android pada materi program linear dinyatakan valid dan praktis sehingga dapat memudahkan siswa dalam proses pembelajaran baik di dalam maupun di luar kelas. Selain itu media pembelajaran matematika berbasis android ini dapat memudahkan siswa belajar secara mandiri dan berulang-ulang hingga paham dimanapun dan kapanpun.

Namun, berdasarkan penelitian dan pengembangan yang telah dilakukan, ada beberapa saran untuk memperbaiki media yang telah dikembangkan antara lain ujicoba ke siswa masih terbatas ke 10 orang, akan lebih baik jika dilanjutkan ujicoba ke kelompok yang lebih besar untuk mengetahui efektifitas media. Selain itu, media ini belum tersedia di PlayStore sehingga belum bisa diunduh secara umum.

\section{DAFTAR PUSTAKA}

Depdiknas. 2005. Peraturan Pemerintah RI Nomor 19 tahun 2005 tentang Standar Nasional Pendidikan. Jakarta. Depdiknas.

Huda, A.A. 2013. 9 Aplikasi Android Buatan Sendiri. Yogyakarta: CV Andi Offset.

Purbasari, R.J., Kahfi, M.S., dan Yunus, M. 2012. Pengembangan Aplikasi Android Sebagai Media Pembelajaran Matematika Pada Materi Dimensi Tiga Untuk Siswa SMA Kelas X. Jurnal Pendidikan Matematik Vol.1. No.2. Universitas Negeri Malang.

Purwanto, Y. dan Rizki, S. 2015. Pengembangan Bahan Ajar Berbasis Kontekstual Pada Materi Himpunan Berbantu Video Pembelajaran. AKSIOMA Jurnal Pendidikan Matematika, Volume 4. No.1, hal 67-77. Universitas Muhammadiyah Metro

Rahmawati, A. dan Rizki, S. 2017. Pengembangan Bahan Ajar Berbasis Nilai-nilai Islam Pada Materi Aritmatika Sosial. AKSIOMA Jurnal Pendidikan Matematika. Volume 6. No.1, hal 81-88.

Riduwan dan Akdon. 2013. Rumus Data Dalam Aplikasi Statistika. Bandung: Alfabeta.

Sukmadinata, N. S. (2011). Metode Penelitian Pendidikan. 
ISSN 2089-8703 (Print) Vol. 7, No. 1 (2018)

ISSN 2442-5419 (Online)

Bandung: $\quad$ PT Remaja

Rosdakarya Offset.

Susilana, R. dan Riyana, C. 2009. Media Pembelajaran. Bandung: CV Wacana Prima.

Sutarti, T. dan Irawan, E. 2017. Kiat Sukses Meraih Hibah Penelitian Pengembangan. Yogyakarta: Deepublish.

Yahya, M.A. 2015. Pengembangan Media Pembelajaran Interaktif Berbasis Android Materi Pelajaran Teknik Elektronika Dasar Kelas X Program Studi Keahlian Elektronika Industri $D i$ SMK. Skripsi. Yogyakarta: Universitas Negeri Yogyakarta. 